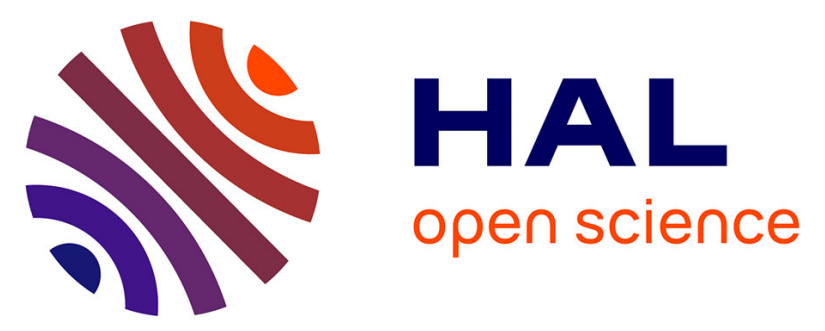

\title{
Physico-chemical properties and surface characterization of renewable hybrid nanofilms interacting with model proteins
}

\author{
Antigoni Theodoratou, Luca Costa, Laurent Bonnet, Christophe Blanc, \\ Vincent Lapinte, Pascal Etienne, Pierre-Emmanuel Milhiet, Jean-Jacques \\ Robin, Julian Oberdisse, Joel Chopineau, et al.
}

\section{To cite this version:}

Antigoni Theodoratou, Luca Costa, Laurent Bonnet, Christophe Blanc, Vincent Lapinte, et al.. Physico-chemical properties and surface characterization of renewable hybrid nanofilms interacting with model proteins. European Polymer Journal, 2019, 111, pp.161-169. 10.1016/j.eurpolymj.2018.12.018 . hal-01974331

\section{HAL Id: hal-01974331 \\ https://hal.science/hal-01974331}

Submitted on 28 Jul 2020

HAL is a multi-disciplinary open access archive for the deposit and dissemination of scientific research documents, whether they are published or not. The documents may come from teaching and research institutions in France or abroad, or from public or private research centers.
L'archive ouverte pluridisciplinaire HAL, est destinée au dépôt et à la diffusion de documents scientifiques de niveau recherche, publiés ou non, émanant des établissements d'enseignement et de recherche français ou étrangers, des laboratoires publics ou privés. 


\title{
Physico-chemical properties and surface characterization of renewable hybrid nanofilms interacting with model proteins
}

\author{
Antigoni Theodoratou ${ }^{\dagger}$ Luca Costa, ${ }^{\sharp}$ Laurent Bonnet, ${ }^{\ddagger}$ Christophe Blanc, ${ }^{\dagger}$ Vincent Lapinte, ${ }^{\dagger}$ Pascal \\ Etienne, ${ }^{\ddagger}$ Pierre-Emmanuel Milhiet,,${ }^{\sharp}$ Jean-Jacques Robin, ${ }^{\dagger}$ Julian Oberdisse, ${ }^{\dagger}$ Joël Chopineau, ${ }^{\dagger}$ Anne \\ Aubert-Pouëssel ${ }^{\dagger}$ \\ ${ }^{\dagger}$ Institut Charles Gerhardt Montpellier (ICGM), UMR5253 CNRS-UM-ENSCM, place Eugène \\ Bataillon, 34090 Montpellier, France. \\ $\not$ Laboratoire Charles Coulomb (L2C), UMR5221 CNRS-UM F34095, Montpellier, France \\ \#Centre de Biochimie Structurale, CNRS UMR 5048 - INSERM UMR 1054 - UM, 34090, \\ Montpellier, France
}

Keywords: hybrid nanofilms, QCM-D, fibroblasts, lysozyme, bovine serum albumin.

\begin{abstract}
A comprehensive characterization of physical-chemical properties and biological interactions of ca. 200-nm-thick hybrid films based on silylated (inorganic part) castor oil (organic part) is proposed. A series of such nanofilms was fabricated and cross-linked by a sol-gel procedure, and their properties such as hydrophilicity, hardness and water vapour transmission rate were systematically studied as a function of the ratio of silylated agent to castor oil. It was found that the nanofilms have contact angles always below $90^{\circ}$, tunable Young modulus and hardness in the MPa range. Moreover, their water vapour transmission rates are increased by decreasing the silica ratio. The protein adsorption and cytocompatibility were evaluated using model proteins and cells. The adsorption of the proteins bovine serum albumin (BSA) and lysozyme was characterized using a quartz crystal microbalance in energy dissipation mode (QCM-D), and atomic force microscopy (AFM). The combination of the latter provided evidence for the different affinities of the proteins with the films. It was found that BSA and lysozyme form rigid layers on the surface with surface coverage close to $30 \%$, and that both protein layers decrease their thickness after their dehydration. Finally, cell culture experiments exhibited a good viability of the fibroblasts compared to ultra-low adhesion surfaces, which makes them potential candidates for biomedical applications.
\end{abstract}




\section{INTRODUCTION}

Vegetable oils as a renewable chemical feedstock play a key role during the last century as renewable resources for the synthesis of polymeric materials such as polyurethanes and natural biomaterials, due to the increasing price of unsustainable crude oil and its environmental impact. During the last decades the research of new biomaterials in the medical field has been increased with many applications in orthopedy (joints, ligaments) [1], dentistry [2], pharmacy (drug delivery systems and wound healing) [3] and tissue engineering [4]. Although synthetic materials like poly(lactic acid) and natural polymers like chitosan [5], sodium alginate [6] and collagen [7] have been employed for the fabrication of biomaterials they exhibit poor mechanical properties. Among the most promising and environmentfriendly biopolymers, vegetable oil-based materials seem to be relevant (and promising) candidates to replace conventional petroleum based polymers in the biomedical field because of their low levels of toxicity, biodegradability and inexpensiveness.

Castor oil extracted from Ricinus communis plant, is a non-edible oil mostly composed of ricinoleic acid that contains hydroxyl groups. The hydroxyl groups make castor oil an amazing candidate for functionalization with a versatile chemistry producing polyurethanes and eco-friendly polymeric materials for many applications [8-10]. The industrial importance of castor oil is also based on its versatility because of its various modifications of the double bonds that can be transformed into epoxide groups, becoming a more reactive precursor for use in several applications [11]. The drawbacks of polyurethanes include their slight cytotoxicity and slow degradability [8]. However, a recent work by Li et al. has shown that waterborne polyurethanes blended with protein soy isolates can have good cytocompatibity properties and improved biodegradability [12]. 
Organic-inorganic hybrid materials based on vegetable oil have been found to exhibit very good properties in terms of thermal stability and abrasion resistance with high compatibility with cells $[13][14,15]$. The inorganic part, usually siloxane networks, is formed using sol-gel chemistry via a hydrolysis/condensation reaction of the alkoxy groups with other silanols $[16,17]$. The cross-linking reaction allows the incorporation of the silica into the organic component creating interpenetrating (cross-linked) siloxane networks. The amount of the sol-gel precursor has been discussed in the literature leading to tunable hybrid materials in terms of hydrophobicity, hardness, adhesion and mechanical resistance $[14,17$, 18]. Despite that, there is little evidence in the literature about the interactions of vegetable oil-based hybrid materials with biological media, especially with proteins. Contrary to the present study, the classically used process in the literature to make vegetable oil-based hybrid materials requires toxic solvents and thermal treatments that has an impact either on the physical properties of the films or on their behaviour in contact with biological media. The surface interactions with biological media are seldom described in the literature, especially the interactions of vegetable oil-based hybrid materials with proteins.

Protein adsorption has been a topic of interest in the field of biomaterial science, since the implantation of a polymeric material into the body is accompanied by protein adsorption and subsequent cell interaction. Therefore, the development of biomaterials requires compatibility in living tissue, protein adsorption (closely linked to biocompatibility) and cytocompatibility studies [19]. The driving forces that rule protein adsorption are electrostatic interactions, van der Waals forces, hydrogen bonding and hydrophobic interactions [20]. The control parameters can be the surface chemistry, charge, topography, roughness and hydrophobicity $[21,22]$. The mechanism of adsorption and the conformational changes of proteins have been studied extensively, as well as the models which describe it [23, 24]. Several techniques are available for this purpose, atomic force microscopy [25], ellipsometry 
[26] and QCM-D [27, 28], with the latter one being the most sensitive technique in terms of high resolution mass detection in the limits of $1.8 \mathrm{ng} / \mathrm{cm}^{2}$. This technique is also able to detect the rigidity or the softness of the adsorbed layers by monitoring the energy dissipation. In this work we have chosen two model proteins, bovine serum albumin (BSA) and lysozyme (LSZ). BSA is an intermediate size plasma protein and it has been studied when it is adsorbed onto several surfaces such as silicon, gold, mica and self-organizing polyelectrolytes [29, 30]. On the other hand, lysozyme is a small and rigid protein which has been extensively studied on silica [31], gold and polyHEMA [32]. Up to our knowledge, there is no systematic study of the protein adsorption onto vegetable-oil hybrid films using the QCM-D technique.

The objective of this study was to thoroughly characterize the physico-chemical properties of nanometer-scale organic-inorganic coatings of silylated castor oil, and link it to its interaction with biological material, namely model proteins. A series of castor oil-based hybrid coatings was prepared through a sol-gel process based on the direct functionalization of the triglycerides followed by a hydrolysis and condensation, avoiding epoxidation and subsequent ring-opening reactions. Nanometric-sized films were obtained using spin-coating contrary to our previous work where micrometric sized films were prepared at the air-water interface [33]. Moreover, the effect of the molar ratio between the silica precursor to castor oil $\left(\mathrm{X}_{\mathrm{R}}\right)$ on hydrophilicity and water-vapour transmission rate are here deeply studied, which are prerequisites to biomedical applications and food packaging. Finally, cytotoxicity tests were performed with both the bare hybrid nanofilms and the protein-coated films in order to evaluate their potential as future biomaterials. 


\section{EXPERIMENTAL SECTION}

2.1 Materials. Pharmaceutical grade castor oil $\left(\mathrm{CO} ; \mathrm{MW}=934 \mathrm{~g} \cdot \mathrm{mol}^{-1}\right)$ was purchased from Cooper Pharmaceutique. 3-(Triethoxysilyl) propyl isocyanate (IPTES; MW $=247.4 \mathrm{~g} \cdot \mathrm{mol}^{-1}$ ) and dibutyltin dilaurate $\left(\mathrm{DBTDL} ; \mathrm{MW}=631.6 \mathrm{~g} \cdot \mathrm{mol}^{-1}\right.$ ) were supplied by Sigma-Aldrich and were used without any extra purification. For the protein adsorption studies bovine serum albumin and lysozyme from chicken egg white were used and Dulbecco's phosphate buffered saline (PBS) from GIBCO. Cytotoxicity tests were performed with NIH 3T3 fibroblast cells (continuous cell line from mouse embryo) which were bought from ATCC.

2.2 Preparation of castor oil films. Castor oil was functionalized with the silica precursor (IPTES) using a solvent free reaction in the presence of a catalyst $(0.8 \% \mathrm{w} / \mathrm{w}$ of DBTDL) in order to modify castor oil with cross-linkable functions (ICO). We worked with several functionalization degrees, by varying the molar ratio of isocyanate (NCO) of the silica precursor to hydroxyl groups $(\mathrm{OH})$ of the castor oil, using the parameter $\mathrm{X}_{\mathrm{R}}\left(\mathrm{X}_{\mathrm{R}}=\mathrm{n}_{\mathrm{NCO}} / \mathrm{n}_{\mathrm{OH}}\right)$ which ranges from 0.33 up to 1 . The ATR-IR spectra of the films with different $X_{R}$ ratios are shown in supporting information (Fig. S1).

ICO coatings were prepared by spin-coating (SPS, SPIN 150-v3). ICO was dissolved in chloroform at a concentration of $c=20 \mathrm{mg} \cdot \mathrm{mL}^{-1}$ and $30 \mu \mathrm{L}$ of the solution were deposited onto the circular glass supports and silica q-sensors. The supports were spun at $2000 \mathrm{rpm}$ for 2 min and immediately after the samples were placed inside an oven at $120{ }^{\circ} \mathrm{C}$ for $24 \mathrm{~h}$ in order to accelerate the sol-gel reaction and the cross-linking via the hydrolysis and condensation reaction. The films were subjected into an extensive cleaning procedure in 
order to remove impurities and residual reactants. In more detail, they were soaked in ethanol for 3 days, they were washed with Milli-Q water and left in the drying chamber for $2 \mathrm{~h}$ at 80 ${ }^{\circ} \mathrm{C}$. Finally, the films were further cleaned by UV-ozone (PSD-UV Benchtop UV-Ozone Cleaner, Novascan) for $15 \mathrm{~min}$ and stored under vacuum.

\subsection{Characterization techniques.}

Attenuated total reflection infrared spectroscopy (FTIR-ATR) was performed with a spectroscope (Spectrum 100, Perkin Elmer) for the structural characterization of the castor oil hybrid films, especially in order to monitor the influence of the $X_{R}$ ratio on the film's crosslinking. The contact angle measurements were performed with a DataPhysics OCA - Series device using water as solvent. The shape of the drops $(5 \mu \mathrm{L})$ onto the films was captured with a CCDs camera and the reported contact angles were the average of at least 10 measurements.

The nano-indentation measurements have been performed with an Anton Paar ultranano-indentor using a Berkovich diamond tip at room temperature. During these measurements, the space between the indents was fixed at $30 \mu \mathrm{m}$ in order to prevent any interaction and the indentation speed was $40 \mu \mathrm{N} \mathrm{min}{ }^{-1}$. For these measurements we used films with increased thickness (up to a few microns) to avoid finite size effects on the force measurements. With this method we measured the loading force $(\mathrm{P})$ as a function of the penetration depth (h) curves until a predefined maximum force of $80 \mu \mathrm{N}$ and subsequently the unloading curves. Using the slope $(S)$ at the beginning of the unload curve, we could extract the Young modulus (E) of the material according to the following relations:

$$
E^{*}=\frac{\sqrt{\pi}}{2 \beta} \frac{\mathrm{S}}{\sqrt{\overline{\mathrm{A}}_{\mathrm{P}}}} \quad \text { and } \frac{1}{E^{*}}=\frac{1-v^{2}}{E}+\frac{1-v_{i}^{2}}{E_{i}}
$$

where 
$\beta$ : the geometrical constant depending of the shape of indenter (1.034 in the present case),

$\mathrm{E}_{\mathrm{i}}$ : the indenter's Young modulus,

$v_{\mathrm{i}}$ : the Poisson ratio of the sample, which has been fixed at 0.4 for all measurements as a compromise between polymers and elastomers corresponding to the mean behaviour of our films.

The hardness $(H)$ has been calculated at the maximum force according to: $H=\frac{F}{A_{P}}$, where $F$ is the maximum force and $\mathrm{A}_{\mathrm{p}}$ is the surface contact area between the indenter and the sample.

In order to evaluate the water vapour transmission rate (WVTR) of the ICO films we created films with thickness of $188 \pm 10 \mu \mathrm{m}$ according to the method that we have reported recently.[33] These films were cut in circular shapes with an area of $9.0810^{-4} \mathrm{~m}^{2}$. A glass container was filled with water and afterwards the circular films were stabilized within the container at a distance of $1 \mathrm{~cm}$ from the surface of the water. The system was stored within a desiccator under controlled humidity (10\% relative humidity) and temperature $\left(23{ }^{\circ} \mathrm{C}\right)$ conditions. The weight of the whole container was measured 2 times per day for 5 days. From the linear slope of the total mass versus the time we extracted the diffusion constant which corresponds to the water vapour transmission rate (WVTR) if it is divided by the film's area [34].

Quartz crystal microbalance with dissipation (QCM-D) measurements were performed with a $Q$-Sense E1 (Biolin Scientific AB) apparatus. The $\mathrm{SiO}_{2}$ coated q-sensors had an AT-cut, fundamental frequency of $4.95 \mathrm{MHz}$ and a diameter of $14 \mathrm{~mm}$. The sensors were coated with the functionalized castor oil according to the procedure described in the section 2.2. In all the experiments, in order to obtain a stable baseline, we kept on injecting PBS overnight. All the experiments were performed at $25{ }^{\circ} \mathrm{C}$ and with a flow rate of 20 $\mu \mathrm{L} \cdot \mathrm{min}^{-1}$. The proteins (BSA and lysozyme) were dissolved in PBS $\left(c=0.5 \mathrm{mg} \cdot \mathrm{mL}^{-1}\right)$ and 
were flowed for $4 \mathrm{~h}$ in order to reach the adsorption plateau. Afterwards, PBS was flowed for $1 \mathrm{~h}$ in order to obtain the final baseline of the protein adsorption. In all experiments, new sensors coated with ICO were used each time. During the experiments, two parameters were recorded: the frequency shift $(\Delta \mathrm{F})$ and the energy dissipation $(\Delta \mathrm{D})$. The decay curve of the oscillation was fitted using the following mathematical expression:

$$
\mathrm{A}(\mathrm{t})=A_{O} \exp \left(-\frac{t}{\tau}\right) \sin (2 \pi F+\varphi)
$$

where $\tau$ is the decay time and $A_{O}$ the initial oscillation amplitude at time $\mathrm{t}=0$. From eq. 2 , we evaluated the dissipation as $\mathrm{D}=1 / \pi F \tau$. In case of very small dissipation values (i.e $\Delta \mathrm{D} \sim 1 \cdot 10^{-}$ ${ }^{6}$ ) we could apply the Sauerbrey relation which relates the adsorbed mass per unit area $(\Delta \mathrm{m})$ with the frequency shift $(\Delta \mathrm{F})$ according to the following relation [35]:

$$
\Delta \mathrm{m}=\frac{-C \Delta \mathrm{F}}{n}
$$

where $C=17.7 \mathrm{ng} / \mathrm{cm}^{2} \cdot \mathrm{Hz}^{-1}$ and $n$ the overtone number $(1,3,5,7,9,11,13)$.

Atomic Force Microscopy (AFM) experiments were performed on a Nanowizard 4 AFM (JPK Instruments) equipped with a Tip Assisted Optics (TAO) module. The AFM head was mounted on a commercial inverted optical microscope (Axio Observer, Carl Zeiss). The images of the films coated with BSA and lysozyme were recorded with the tip immersed in the liquid (PBS) hydrating the samples immediately after the experiments with the QCMD. In addition, AFM imaging was performed on pure ICO nanofilms and on the protein coated nanofilms in dry conditions after 2 days storage of the samples in a desiccator under vacuum (circular and made of heavy glass). Images were acquired in "Quantitative Imaging" (QI) mode, a fast force curve imaging mode [36], with Silicon tips mounted on MSNL cantilevers (Bruker), with nominal spring constants of $0.03,0.1$ and $0.6 \mathrm{~N} / \mathrm{m}$. AFM images were collected with 256 x 256 pixels and with scan size of $10 \mu \mathrm{m}$ X $10 \mu \mathrm{m}, 2 \mu \mathrm{m}$ X $2 \mu \mathrm{m}, 1 \mu \mathrm{m}$ 
$\mathrm{X} 1 \mu \mathrm{m}$ and 500nm X 500nm at a tip-sample repulsive force set-point of approximately 100 $\mathrm{pN}$ and $500 \mathrm{pN}$ in hydrated and dry conditions, respectively. The length of the force curves performed in QI imaging mode was extended to 500-700 nm in air because of higher attractive forces compared to the hydrated case, a larger length was set in dry conditions to permit to separate AFM probe and sample during a single oscillation cycle. Data were collected on three different sample regions at least. Images, data analysis, flattening as well as statistical evaluation of film coverage, roughness and thickness in AFM images were carried out using Gwyddion Software [37, 38]. Films thickness was evaluated by subtracting the average height of the protein film and the average height of the castor oil film, both quantified from the height pixel dispersion showing a bimodal Gaussian distribution. Surface coverage was obtained using a threshold method on the image height values to separate covered from uncovered sample regions. The surface coverage was then evaluated as $\varphi=$

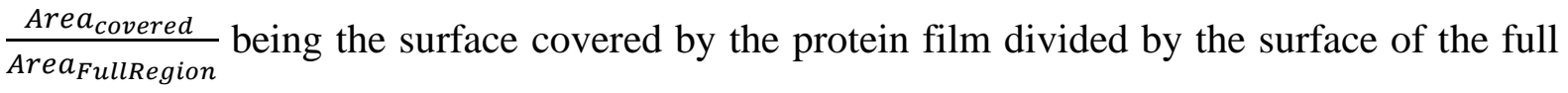
AFM image.

The cytocompatibility of hybrid nanofilms was assessed with NIH 3 T3 fibroblasts. Their in vitro growth was monitored by microscopy and their proliferation capacity was studied with the method of CellTiter $96^{\circledR}$ AQ cell proliferation assay (Promega) made by a tetrazolium compound (3-(4,5-dimethylthiazol-2-yl)-5-(3-carboxymethoxyphenyl)-2-(4sulfophenyl)-2H-tetrazolium, inner salt; MTS). The films were placed into an ultra low adhesion (ULA) 96-well culture dish plate which prevents the attachment of cells. $20 \mu \mathrm{L}$ of solutions $\left(\mathrm{c}=1 \mathrm{mg} \cdot \mathrm{mL}^{-1}\right)$ of BSA and lysozyme in PBS were added and rested for $4 \mathrm{~h}$ at 37 ${ }^{\circ} \mathrm{C}$. The experiments were performed in triplicate. Afterwards, the protein solutions were removed by aspiration and 5000 cells were added in each well and the cells were kept for 24 $\mathrm{h}$ at $37{ }^{\circ} \mathrm{C}$ and $5 \% \mathrm{CO}_{2}$ in a humidified incubator. The used culture medium was serum free, 
i.e without proteins, to optimize the effect of the studied proteins (BSA and lysozyme). At 24 and $48 \mathrm{~h}$, microscopy images were obtained using an EVOS microscope. In order to evaluate further the viability of the cells after $48 \mathrm{~h}$ of incubation, $20 \mu \mathrm{L}$ of MTS-PMS mixture was added in each well and after $4 \mathrm{~h}$ the living cells were quantified using a microplate reader (Multiskan Go, Thermo Fisher Scientific) at $490 \mathrm{~nm}$.

\section{RESULTS AND DISCUSSION}

\subsection{Tunability of physico-chemical properties of castor oil nanofilms.}

The hydrophilic/phobic character of the ICO nanofilms was studied by static contact angle measurements after extensive washing of the surfaces of the films. During all measurements $5 \mu \mathrm{l}$ of water were deposited on the surfaces of the films and subsequently the contact angles of the drops were extracted. The effect of the $X_{R}$ ratio on the hydrophilicity of the films is summarized in Table 1 . All the nanofilms, whatever $\mathrm{X}_{\mathrm{R}}$ ratio, were found to exhibit slight hydrophilic behaviour since the contact angles were below $90^{\circ}$ for all $\mathrm{X}_{\mathrm{R}}$ ratios. Thus, the hydrophilicity of the films was tuned by the silica ratio by obtaining more hydrophilic surfaces with low $X_{R}$. The contact angles in general are related to the micro-nano roughness of the surface. According to Meera et al. [17], castor oil polyurethanes without siloxane networks exhibit a contact angle of $74^{\circ}$ and the addition of siloxane networks is expected to increase the hydrophobicity of the polyurethanes due to changes in the surface roughness of the material. Li et al. recently reported soy-protein modified waterborne polyurethanes made by castor oil with tunability of contact angles which range from $55-100^{\circ}$ by variation of the soy protein isolate [12]. Also, in the literature the formation of hydrophilic castor oil polymeric films $\left(62-80^{\circ}\right)$ reinforced with chitosan-modified $\mathrm{ZnO}$ nanoparticles have been reported by Diez et al. while hydrophobic coatings (97-130 ) using epoxidised castor oil 
mixed with different siloxane agents have been reported by Mulazim et al. [3, 39, 40]. Consequently, the tunability of the silylated castor oil nanofilms' hydrophilicity, reflected by contact angles ranging in the angular window $72^{\circ}-88^{\circ}$ makes our films potential candidates for applications requiring interactions with biological agents and drug delivery.

Table 1: Water contact angles and water vapour transmission rates for different $X_{R}$ ratios.

\begin{tabular}{|c|c|c|c|c|}
\hline Name & $\begin{array}{c}\text { NCO:OH } \\
\text { Molar } \\
\text { ratio }\left(\mathrm{X}_{\mathrm{R}}\right)\end{array}$ & $\begin{array}{l}\text { Water } \\
\text { contact } \\
\text { angle }\left(^{\circ}\right)\end{array}$ & $\begin{array}{c}\text { WVTR } \\
\left(\mathrm{mol} / \mathrm{d} \cdot \mathrm{m}^{2}\right)\end{array}$ & $\begin{array}{l}\text { Relative } \\
\text { Error \% } \\
\text { of WVTR }\end{array}$ \\
\hline$\overline{\mathbf{X}_{\mathbf{A}}}$ & 1.00 & $88 \pm 3$ & 1.09 & 13 \\
\hline $\mathbf{X}_{\mathbf{B}}$ & 0.80 & $85 \pm 6$ & 1.93 & 12 \\
\hline $\mathbf{X}_{\mathbf{C}}$ & 0.66 & $80 \pm 7$ & 1.28 & 40 \\
\hline $\mathbf{X}_{\mathbf{D}}$ & 0.50 & $78 \pm 5$ & 2.5 & 30 \\
\hline $\mathbf{X}_{\mathbf{E}}$ & 0.33 & $72 \pm 5$ & 6.09 & 10 \\
\hline
\end{tabular}

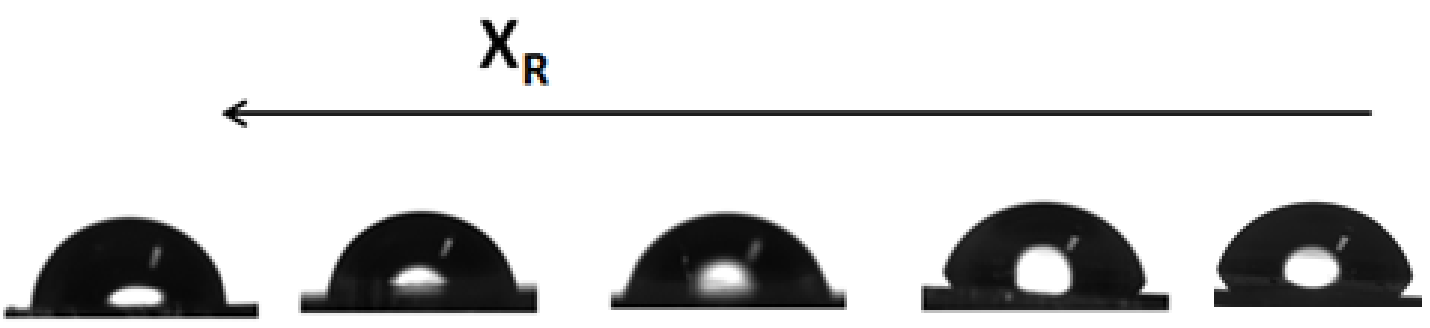

Figure 1: Hydrophilicity of ICO nanofilms by water contact angle measurements for films with different $X_{R}$ ratios. From right $\left(X_{R}=0.33\right)$ to left $\left(X_{R}=1\right)$ the silica to castor oil ratio is increased.

Another important property of films, especially for wound healing applications is their WVTR, which refers to the amount of the water vapour that is diffused through the film for a certain period of time under specific relative humidity and temperature conditions. 
Accordingly, in order to avoid dehydration and favour perspiration retention, the design of coating materials for biomedical applications should be optimized [41]. Here, the effect of the $\mathrm{X}_{\mathrm{R}}$ ratio of the castor oil hybrid nanofilms on the WVTR properties has been studied and the results are presented in Table 1. By decreasing the amount of siloxane networks the WVTR of the films seemed to increase by a factor of 6 pointing out that the permeability of the films is getting higher. We have to notice that our data include a relative error which ranges from $10 \%$ to $40 \%$. This value is somewhat large, but is still acceptable for this kind of measurements [42]. It was expected that the decrease of the siloxane networks favours the mass transfer of the water molecules through the polymeric matrices. Comparing the barrier properties and contact angle results (Table 1) we could relate the increase of the WVTR of the films with the increased hydrophilic properties of the films which contain the minimum amount of siloxane networks $\left(\mathrm{X}_{\mathrm{E}}=0.33\right)$.

Commercial wound dressings exhibit WVTR values which range from 189 to 383 $\mathrm{g} / \mathrm{d} \cdot \mathrm{m}^{2}$ measured with the method of ASM E96-80 (for relative humidity of $\left.34 \%\right)[3,43],(50$ $\mathrm{g} / \mathrm{d} \cdot \mathrm{m}^{2}$ for low permeable until $4000 \mathrm{~g} / \mathrm{d} \cdot \mathrm{m}^{2}$ for high permeable devices) [44]. However, a fair comparison is not trivial given that the methods in the literature for measuring WVTR vary as well as the experimental conditions (i.e. relative humidities and temperatures). Thereupon, we have chosen two commercial films for wound dressing, Apoplaie ${ }^{\circledR}$ (Apothicare) and Hydrofilm ${ }^{\circledR}$ (Hartmann), and we have measured their WVTR in the same conditions that were applied for the castor oil hybrid films measured in this work. The WVTR of these films were for Apoplaie and Hydrofilm, $34.7 \mathrm{~mol} / \mathrm{d} \cdot \mathrm{m}^{2}$ (5.7 times higher than $\mathrm{X}_{\mathrm{E}}$ ) and $21.5 \mathrm{~mol} / \mathrm{d} \cdot \mathrm{m}^{2}$ (3.5 times higher than $\mathrm{X}_{\mathrm{E}}$ ), respectively, which are in the same range to the values obtained for ICO nanofilms. To conclude, the WVTRs found in this study for castor oil hybrid nanofilms show that the cross-linking decrease $\left(\mathrm{X}_{\mathrm{R}}\right.$ from 1 down to 0.33$)$ can modify the barrier properties by a factor of 6 , making these materials potentially ideal for 
uses as thin-film coatings of implants and wound dressings that are currently fabricated with conventional polymeric coatings.

The tunability of the mechanical properties of solid films is an important feature for a coating that is going to be applied in biomedical applications. We have used the $\mathrm{X}_{\mathrm{R}}$ ratio as a parameter to tailor the Young modulus and hardness of the castor oil hybrid nanofilms. Measurements were performed using the nano-indentation method. Nano-indentation measurements determined the nanomechanical properties on the surface of the nanofilms with a penetration depth of $800 \mathrm{~nm}$. In Figure $2 \mathrm{a}$ we present the load-unload curves as a function of the penetration depth for different $X_{R}$ ratios where a horizontal shift is observed for smaller $\mathrm{X}_{\mathrm{R}}$ because the films become softer. A comparison between the nanofilm's Young modulus and hardness is shown in Figure $2 \mathrm{~b}$. The Young modulus and hardness had the following trend:

$$
\mathrm{X}_{\mathrm{A}}(1.0)>\mathrm{X}_{\mathrm{B}}(0.8)>\mathrm{X}_{\mathrm{C}}(0.67)>\mathrm{X}_{\mathrm{D}}(0.5)>\mathrm{X}_{\mathrm{E}}(0.33)
$$

Thus, the evolution of the Young modulus and hardness was consistent with the cross-linking increase of the nanofilms. It is worth mentioning that it was not trivial to form the softer nanofilm $\left(\mathrm{X}_{\mathrm{E}}\right)$ due to the lack of enough silylated groups that favour the wetting of the oil. For this reason its maximum force differs from the rest of the measurements (100 $\mu \mathrm{N}$ instead of $80 \mu \mathrm{N})$. Consequently, the mechanical properties of the hybrid nanofilms could be tailored by changing the $X_{R}$ ratio obtaining Young moduli between $13<E(M P a)<62$ and hardness between $2<\mathrm{H}(\mathrm{MPa})<21$. These results are compatible with the moduli measured with micrometric films [33], indicating that the spin-coating process did not affect the film's hardness and Young Modulus of the films. 

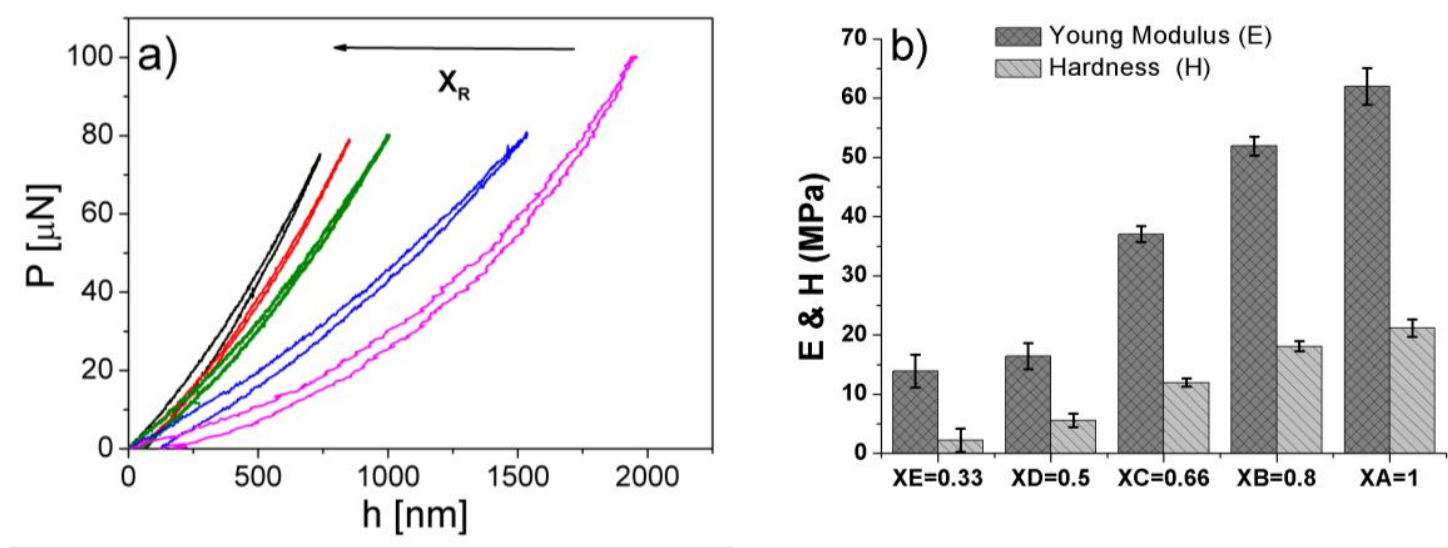

Figure 2: Mechanical properties of castor oil hybrid nanofilms measured by nano-indentation: (a) Loading force $(\mathrm{P})$ as a function of depth by varying $\mathrm{X}_{\mathrm{R}}$ ratio and (b) the extracted Young's modulus and hardness for each $X_{R}$ ratio. The maximum load for $X_{A}-X_{D}$ was $80 \mu N$ and for $X_{E} 100 \mu N$.

\subsection{Castor oil nanofilms: Interactions with model proteins.}

The adsorption of proteins onto nanofilms targeted to be used in biomedical applications is crucial since it can provide information about the biocompatibility of the material. Two model proteins were chosen to be studied in this work using the method of QCM equipped with the dissipation mode in order to provide information about the rigidity (or softness) of the protein coatings onto the ICO nanofilms. QCM-D is able to detect a small quantity of adsorbed mass onto the crystal due to the decrease in the resonance frequency of the oscillation during adsorption, with a low detection limit.

After obtaining a stable baseline (by flowing PBS overnight) the protein solutions were injected and they flowed for 4 hours. After 4 hours of continuous flow the system was rinsed with PBS for one hour (final plateau). The final plateau corresponds to the final adsorption regime of our study. Here, we have considered that after rinsing the system with PBS, the protein is adsorbed "irreversibly". We attempted several trials to remove the proteins from the sensors after QCM-D measurements and re-use them but as we show in SI (Figure 
S2) the ICO nanofilms could not be cleaned totally from the protein using $1 \%$ solutions of SDS. So, here all the measurements were done with new spin-coated ICO nanofilms.

The adsorption of BSA and lysozyme were studied at $25^{\circ} \mathrm{C}$ under continuous flow of the protein solutions with a flow rate of $20 \mu \mathrm{L} / \mathrm{min}$. In Figure 3 we report the raw data of the changes in the normalized frequency $\left(\Delta F_{n}\right)$ and the energy dissipation $\left(\Delta D_{n}\right)$ as a function of time for the two types of proteins, BSA (upper panel) and lysozyme (lower panel). For the sake of clarity in Figure 3 we denote with $\mathrm{t}=1 \mathrm{~h}$ the point at which we inject the protein solution after an overnight flow of the PBS solution kept for $17 \mathrm{~h}$ to obtain a stable baseline. At the final adsorption plateau (here at $\mathrm{t}=5.8 \mathrm{~h}$ ) the dissipation observed for both proteins was close to $\sim 1 \cdot 10^{-6}$ which fulfils the low dissipation condition for applying safely the Sauerbrey relation (eq. 3) associating $\Delta \mathrm{F}$ to the adsorbed mass per unit area. Hence, both proteins form stiff films onto the ICO nanofilms and for this reason viscoelastic models were not applied for the analysis of the data. For the estimation of the protein adsorbed mass we have chosen the regime of final plateau and the $\Delta \mathrm{m}$ was found to be according to eq. $3,319 \pm 40 \mathrm{ng} / \mathrm{cm}^{2}$ and $299 \pm 18 \mathrm{ng} / \mathrm{cm}^{2}$ for BSA and lysozyme, respectively (see Table 2). In Figure 4 a comparison between the two measurements is shown by plotting the adsorption profiles of BSA and Lysozyme. The plateau for BSA is reached 33 min after the protein injection while the process is slower for lysozyme which exhibits a continuous profile increase. According to Teichroeb et al.,[32] lysozyme exhibits concentration dependent adsorption with different time scales, while this is not the case for BSA. It is worth noticing that with lysozyme we did not observe negative dissipation shifts. This indicates that the protein adsorption in our cases occurs on the surface of the ICO nanofilms and not in the matrix of the films, like it has been reported for hydrogel systems like polyHEMA layers [32]. 


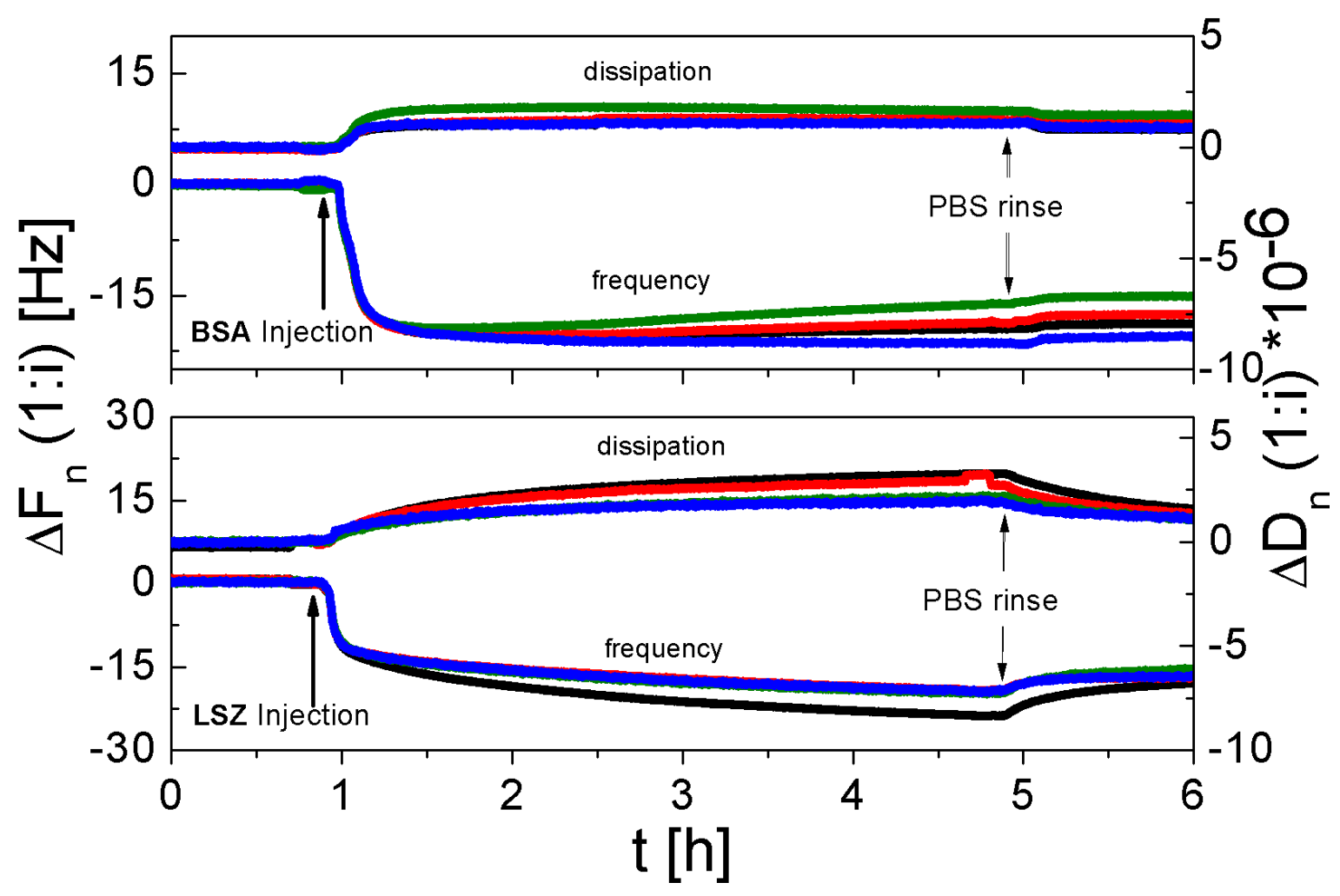

Figure 3: QCM-D results of protein adsorption study on ICO nanofilms. The changes in resonance frequency and the energy dissipation of the crystal are plotted as a function of time for BSA (upper panel) and lysozyme (lower panel). In both panels four overtones are shown: $n=3$ (black colour), $n=5$ (red colour), $n=7$ (green colour) and $n=9$ (blue colour). The baseline has been obtained in both experiments by flowing PBS overnight. After $4 \mathrm{~h}$ of protein solution flow the crystals were rinsed with a protein-free buffer for $1 \mathrm{~h}$. All protein solutions had a concentration of $0.5 \mathrm{mg} / \mathrm{mL}$ in PBS and the experiments were done at $25{ }^{\circ} \mathrm{C}$ using a flow rate of $20 \mu \mathrm{L} / \mathrm{min}$.

We have evaluated from the QCM-D measurements the thickness of the protein layers: $d_{B S A}=8.3 \pm 1.1 \mathrm{~nm}$ and $d_{L S Z}=7.6 \pm 0.5 \mathrm{~nm}$. The calculation of the thicknesses of the adsorbed proteins was done taking into account the percentage of the surface coverage obtained by AFM in liquid $\left(\varphi_{\mathrm{BSA}}=0.29\right.$ and $\left.\varphi_{\mathrm{LSZ}}=0.30\right)$ and assuming $\rho_{\mathrm{BSA}}=\rho_{\mathrm{LSZ}} \sim 1.32 \mathrm{~g} / \mathrm{cm}^{3}$. These values of mass over volume have been used widely in the literature, $[30,32]$ although the density of the hydrated protein layers varies in the literature for lysozyme and BSA in water.[45, 46] A comparison of our data with similar vegetable oil hybrid nanofilms was not 
trivial since there is not enough evidence in the literature regarding protein adsorption of vegetable oil-based hybrid films using the QCM-D method. However, the investigation of pure vegetable oil films adsorbed on q-sensors and aliphatic amines vapours detection on castor oil films has been reported up to now [47, 48]. Comparing our experimental findings with data available in literature for different surfaces, lysozyme adsorption on $\mathrm{SiO}_{2}$ at $\mathrm{pH}$ close to the physiological conditions was $\Delta \mathrm{m}=236.8 \mathrm{ng} / \mathrm{cm}^{2}$, a lower adsorption comparing to ICO films [49]. Also, Jachimska et al. studied the BSA adsorption on $\mathrm{SiO}_{2}$ as a function of $\mathrm{pH}$ with ionic strength of $1 \cdot 10^{-2} \mathrm{M}$ showing that the maximum coverage occurs at $\mathrm{pH}$ range of 4.5-5.4 [30]. However, negatively-charged polystyrene hydrophobic surfaces have been found to increase the adsorption capacity of BSA [29].

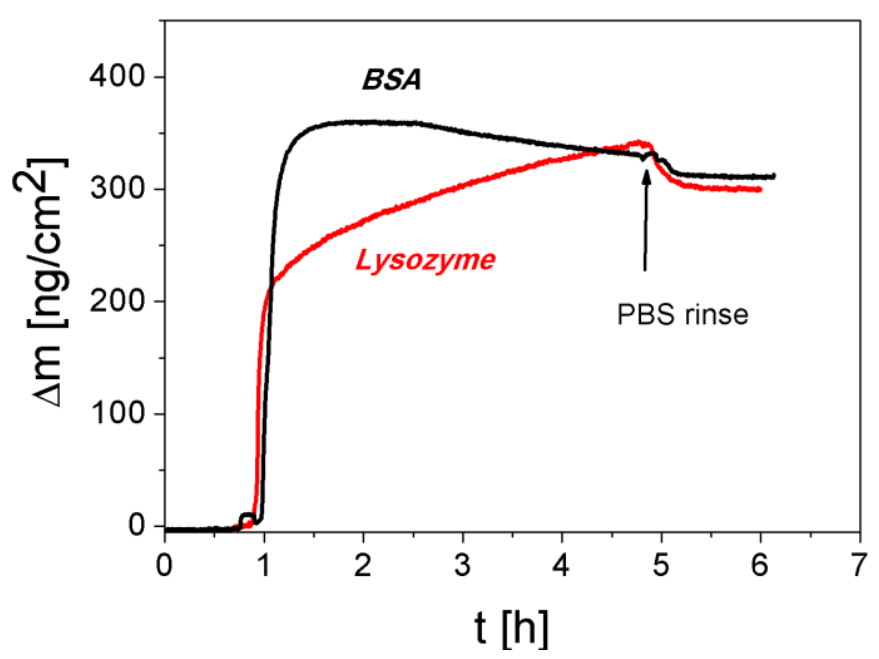

Figure 4: Protein adsorption profiles for BSA and lysozyme after application of the Sauerbrey relation. For both proteins the $5^{\text {th }}$ overtone is presented, BSA (black line) and lysozyme (red line).

Atomic force microscopy measurements were performed in order to extract information about the thickness and the percentage of the surface coverage of the proteins in liquid and in air after drying the protein films. Using the QCM-D, by flowing protein 
solutions on the ICO nanofilms (supported by the q-sensors) we created permanent protein coatings. Those coatings were stored in PBS immediately after the measurement and were used for the AFM tests in liquid and in air (after drying). In SI (Figure S3) we provide the AFM images where we have characterized the thickness of the ICO nanofilms that were used for this study. Their roughness was found to be $5.75 \pm 1.39 \mathrm{~nm}$ and their average thickness 170 $\mathrm{nm}$. The same sensors were used in their dried state for the measurements in air. In Figure 5 we show the topographical images of BSA and lysozyme layers which depend strongly on the presence of liquid or not. All images are accompanied by their corresponding height distributions. The average thickness was estimated from the bimodal height pixel distributions of the castor oil and protein films by fitting with 2 Gaussians and it was defined as the difference between the centers of the two Gaussians. As an error we report the difference between the two centers and square root of the sum of the square of the 2 errors by error propagation.

The values of the thicknesses and coverage are summarized in Table 2, providing a comparison with the QCM-D findings. We have found a good agreement between the QCM$\mathrm{D}$ and AFM-Liquid thicknesses. More specifically, for BSA $\mathrm{d}_{\mathrm{AFM}}=6.5 \pm 5.4 \mathrm{~nm} \& \mathrm{~d}_{\mathrm{QCM}}$ $\mathrm{D}=8.3 \pm 1.1 \mathrm{~nm}$ and for lysozyme $\mathrm{d}_{\mathrm{AFM}}=7.9 \pm 5.5 \mathrm{~nm} \& \mathrm{~d}_{\mathrm{QCM}-\mathrm{D}}=7.6 \pm 0.5 \mathrm{~nm}$. The error observed with AFM measurements in the liquid case indicates heterogeneous distribution of the proteins whereas for the dry case is essentially due to the castor oil film roughness (see Supplementary Figure S3). However, the thickness of the dried proteins is more than 2.5 times lower than in the liquid state and exhibits more pronounced bimodal height distributions. This is not surprising since the hydration of the proteins can increase their volume. In liquid conditions, the proteins form monolayers of spherical objects. In liquid the surface coverage of BSA was found to be $29 \pm 7 \%$ and very similar for lysozyme $(30 \pm 8 \%)$. 
In dried conditions, an increased coverage was found for both proteins, $72 \pm 1 \%$ for BSA and $53 \pm 4 \%$ for lysozyme.

In both cases, BSA and lysozyme exhibit bimodal morphology distributions where the proteins have also an elongated (dehydrated) form. The overall conformations of the proteins at the air-ICO interface as well as at liquid-ICO interface are demonstrated with a cartoon in Figure 6, showing almost a two times decrease in the thickness of the layers in their dried state. From crystallography data BSA either shows a triangle conformation of size $8 \times 8 \times 8 \times$ $3 \mathrm{~nm}$ [30] or an elongated form of size $25 \times 2.1 \times 2.1 \mathrm{~nm}$, this information led us to consider that we have a monolayer of BSA. On the other hand, lysozyme has dimensions of $4.5 \times 3 \times 3$ $\mathrm{nm}$ [50] showing that here maybe bilayers of lysozyme are formed in the liquid state. A thickness variation can be also due to protein stability in dry conditions leading to denaturation and consequently to film thinning or eventually to a variation of the proteinscastor oil nanoscale interaction and in turns of the adhesion strength. However, because of the non-homogeneous distribution of the protein aggregates we cannot estimate systematically the aggregation number of the protein layer. 

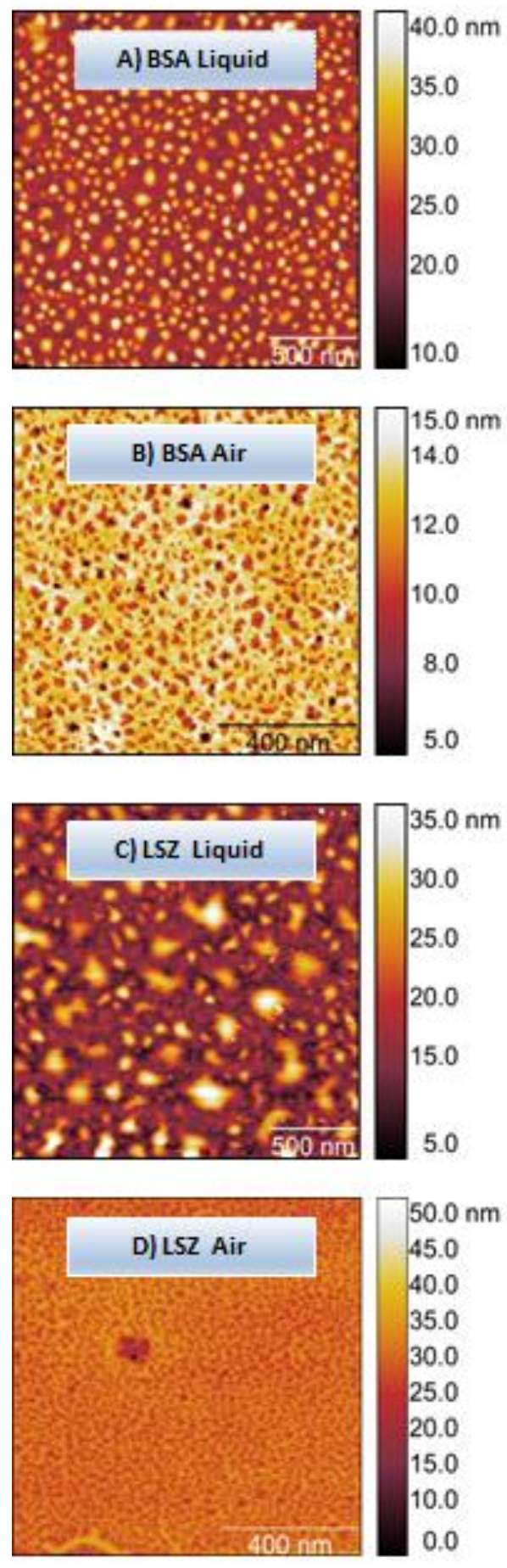
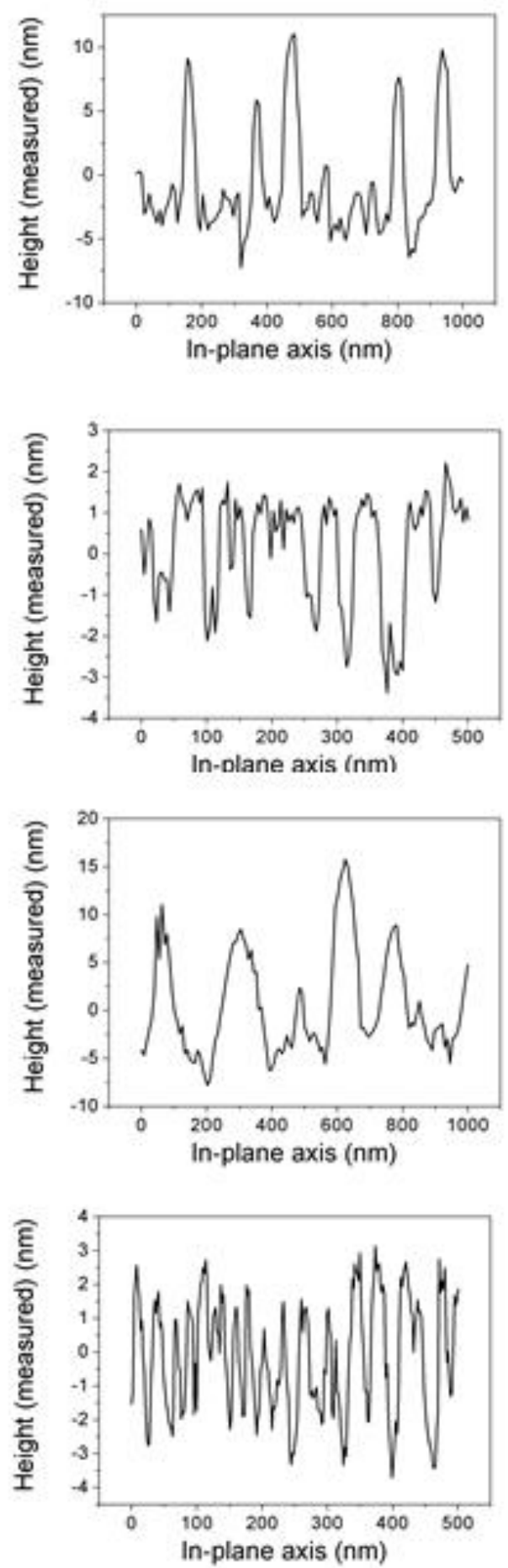

Figure 5: AFM images of protein coatings onto the surface of ICO nanofilms. AFM was performed in liquid with BSA (A) and lysozyme (C) as well as in air after drying the coatings of BSA (B) and lysozyme (D). In the right panels the extracted height profiles are shown for the four aforementioned cases. 
BSA molecules adsorb more on hydrophobic surfaces than on hydrophilic ones and in our case the films are slightly hydrophilic, restricting the maximum protein adsorption. Another crucial parameter for protein adsorption is the $\mathrm{pH}$. According to the literature [51, 52], the maximum adsorption (coverage) of proteins occurs at $\mathrm{pH}$ close to the isoelectric point (IEP) of the protein, for surfaces that are not charged. Here, the $\mathrm{pH}$ of the protein solutions was chosen to be close to the physiological $\mathrm{pH}$ 7.2. The IEP of BSA is 4.5-5.4 and of lysozyme is 9.3 . Hence, in physiological conditions BSA is charged negatively while the lysozyme is charged positively. Both proteins were adsorbed onto zero charged ICO films. Regarding lysozyme, its adsorption on planar surfaces is also highly related to its $\mathrm{pH}$ in solution and more specifically a significant adsorption occurs when the lysozyme is oppositely charged comparing to the surface charge [49].

Table 2: Comparison of experimental data about protein adsorption on ICO nanofilms.

\begin{tabular}{|c|c|c|c|c|c|c|}
\hline & \multirow{2}{*}{\multicolumn{2}{|c|}{ Liquid-QCM-D }} & \multicolumn{4}{|c|}{ AFM } \\
\hline & & & \multicolumn{2}{|c|}{ Liquid-AFM } & \multicolumn{2}{|c|}{ Dry-AFM } \\
\hline & $\begin{array}{c}\mathrm{d} \\
(\mathrm{nm})\end{array}$ & $\begin{array}{c}\Delta \mathrm{m} \\
\left(\mathrm{ng} / \mathrm{cm}^{2}\right)\end{array}$ & $\begin{array}{c}\mathrm{d} \\
(\mathrm{nm})\end{array}$ & $\begin{array}{c}\text { Surface } \\
\text { coverage } \\
(\%)\end{array}$ & $\begin{array}{c}\mathrm{d} \\
(\mathrm{nm})\end{array}$ & $\begin{array}{c}\text { Surface } \\
\text { coverage } \\
(\%)\end{array}$ \\
\hline BSA & $8.3 \pm 1.1$ & $319 \pm 40$ & $6.5 \pm 5.4$ & $29 \pm 7$ & $2.5 \pm 1.4$ & $72 \pm 1$ \\
\hline Lysozyme & $7.6 \pm 0.5$ & $299 \pm 18$ & $7.9 \pm 5.5$ & $30 \pm 8$ & $2.9 \pm 1.6$ & $53 \pm 4$ \\
\hline
\end{tabular}




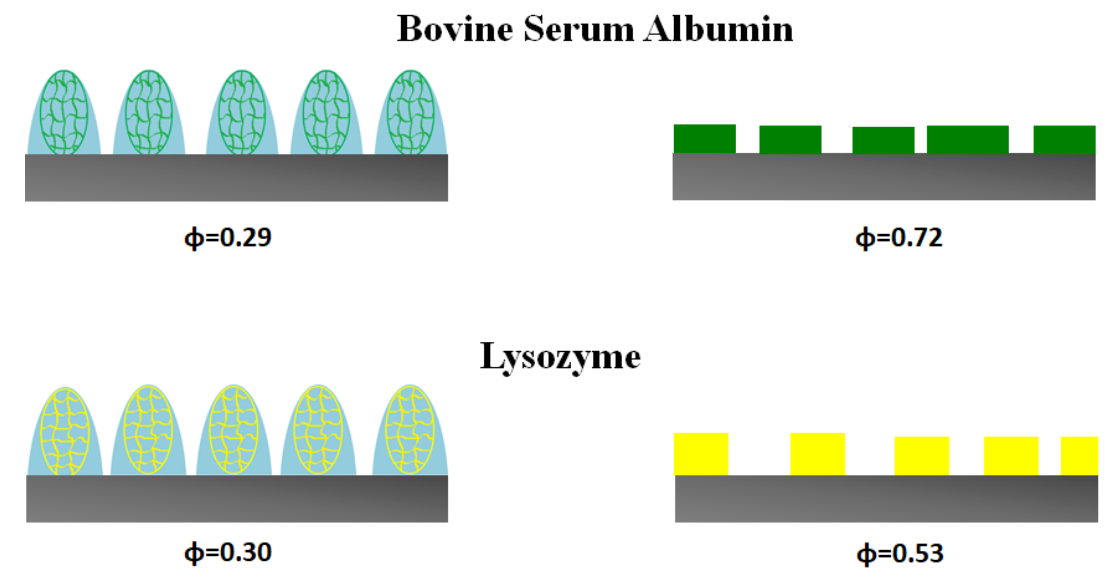

Figure 6: Schematic representation of BSA and lysozyme conformations on ICO films in liquid and in air. The surface fraction is denoted as $\varphi$.

\subsection{Castor oil nanofilms: Interactions with fibroblasts.}

The cytotoxicity of ICO nanofilms with varying silylated agent to castor oil ratio (0.33 to 1.0$)$ as well as their coatings with BSA and lysozyme were assessed using standard viability tests with NIH 3T3 fibroblast cells. MTS tests were performed after incubation time of 20 hours and the results are summarized in Figure 7. As control tests we used ultra-low adhesion plates (ULA) and this cell viability corresponds to a viability of $100 \%$. From our results we observe that ICO coatings significantly $(*)$ improved the cell viability comparing with the control test, 1.2 times more for the $\mathrm{X}_{\mathrm{A}}$ and 1.7 times for the $\mathrm{X}_{\mathrm{E}}$. The cell viability was further improved for the protein coated $\mathrm{X}_{\mathrm{A}}(1.0)$ nanofilm in a significative way $(\bullet)$. Our reference is the cell growth on the ULA plate (ultra-low adhesion plates), which is a hydrophilic surface and cells have difficulty to grow. By modifying this hydrophilic surface with ICO the viability is increased thanks to the lipophilicity of the ICO, the softness of the surface comparing to the hard ULA plates and thanks to the roughness of the ICO surface that favours cell adhesion, hence cell viability. Regarding the improved cell viability on the protein coatings, it has been shown by Reyes et al. that extracellular matrix components such as peptides and proteins can 
significantly improve cell proliferation, and this is why they are used as adhesion agents.[53] It is also interesting to note that lysozyme coatings favour the fibroblast viability comparing to the BSA coatings. This is in agreement with the literature, where albumin is described as a unfavorable protein for fibroblast adhesion [54], whereas lysozyme is usually known for favoring cell adhesion, especially corneal cells [55]. Finally, the more hydrophilic of our nanofilms $\left(\mathrm{X}_{\mathrm{E}}\right)$ exhibited higher cell viability (1.4 times) in comparison with the less hydrophilic nanofilm $\left(\mathrm{X}_{\mathrm{A}}\right)$. Li et al. in a recent study discussed the capacity of fibroblast cells to adhere on a material depending on the material's hydrophobicity/philicity, roughness and microstructure of the surface [12]. In S.I. (Fig. S5) we show the microscopic images taken for the nanofilms and their coatings, showing that the cells can adhere, but they lost their spindle shape.

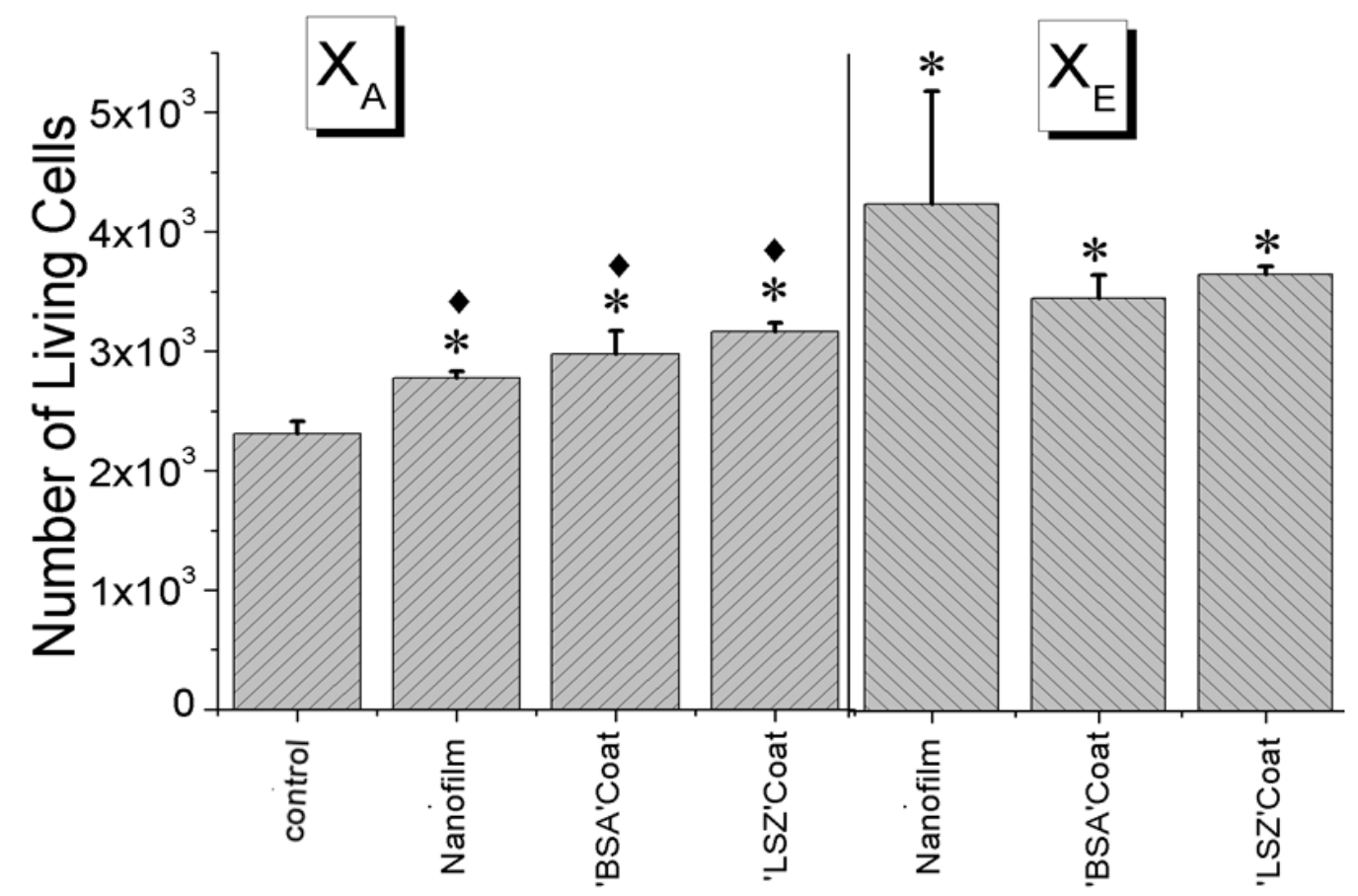

Figure 7: Cytotoxicity using fibroblast cells of ICO nanofilms and their coatings with BSA and lysozyme. The number of living cells is plotted for the two extreme cases of $\mathrm{X}_{\mathrm{A}}$ (left panel) and $\mathrm{X}_{\mathrm{E}}$ (right panel). Control is used as a reference using only cells with ULA wells. A non-parametric MannWhitney test was used to assess for significant differences between the control (*) and the other 
samples of $\mathrm{X}_{\mathrm{A}}$ or $\mathrm{X}_{\mathrm{E}}(\bullet)$ using Minitab $^{\circledR}$ software. A value of $0.05<P<0.1$ was considered statistically significant $(*$ or $\bullet)$.

\section{CONCLUDING REMARKS}

Renewable castor oil-based nanofilms have been prepared and characterized by a combination of techniques. Films have been synthesized by varying the amount of the silylated agent through a sol-gel process. The effect of the amount of silica was studied in terms of tunability of the film hydrophilicity, water vapour transmission rate as well as Young modulus and hardness. The protein adsorption was investigated using a combination of QCM-D and AFM at physiological $\mathrm{pH}$, and finally the cytotoxicity of the bare and proteincoated castor oil nanofilms was tested. We have found that all series of castor oil coatings have contact angles slightly below $90^{\circ}$, revealing the hydrophilic character of these materials. WVTR experiments confirmed that by decreasing the silica precursor to castor oil ratio the hybrid material the film permeability is favored. On the other hand, the increase of silica precursor to castor oil ratio resulted in a systematic increase of the Young modulus and hardness of the ICO nanofilms, tailoring their mechanical properties in the MPa range. In this study BSA and lysozyme were used as model proteins in order to evaluate their adsorption onto the films. QCM-D results revealed that both proteins form rigid layers onto the nanofilms. The homogeneity of the protein layers in liquid and in air was further investigated by using AFM. The results obtained for the average thicknesses were very close to the ones from QCM-D, showing higher roughness with respect to the QCM-D method. The surface coverage in aqueous medium was found for both proteins close to $30 \%$, hence showing that the major part of the substrates is occupied by the phosphate buffer. As expected, while in dried form, the proteins had different coverages, $72 \%$ for BSA and $53 \%$ for lysozyme. Finally, the cytocompatibility of the castor-oil nanofilms with varied silica ratio and protein 
coated nanofilms has been evaluated using fibroblast cells as model cells. MTS cytotoxicity results indicated a high fraction of living cells in comparison to our control reference, showing increased cell viability by reducing the silica precursor to castor oil ratio. The fibroblast cytocompatibility improves when the hydrophilicity increases. ${ }^{53}$ In summary, our study shows by all means that the decrease of the silica precursor to castor oil ratio is accompanied by the increase of the hydrophilicity which is followed by a higher survival of the fibroblast cells and an increase of the WVTR. Based on the findings of this work, the above nanofilms could find several applications in food packaging which requires materials with tunable hydrophilicity, water vapour permeability and hardness. Also, they can be promising candidates as environment-friendly, non-toxic and bio-based materials for biomedical applications because of their biocompatibility to proteins and cytocompatibility to fibroblasts cells.

- AUTHOR INFORMATION

*E-mail: antigoni.theodoratou@umontpellier.fr

\section{- ACKNOWLEDGEMENTS}

The authors thank Marie Morille for the assistance in cytocompatibility experiments and Valérie Guillard for assistance with the barrier property experiments. Also, Nicoletta Giamblanco and Diethelm Johannsmann are gratefully acknowledged for the fruitful discussions about the QCM-D experiments. The CBS is a member of the France-BioImaging (FBI) and the French Infrastructure for Integrated Structural Biology (FRISBI), two national infrastructures supported by the French National Research Agency (ANR-10-INBS-04-01 and ANR-10-INBS-05, respectively). The authors gratefully acknowledge the financial support of this work by Labex CheMISyst and University of Montpellier (UM). 


\section{- REFERENCES}

[1] T. Choi, K.A. Masser, E. Moore, J. Weksler, A. Padsalgikar, J. Runt, Segmented Polyurethanes Derived from Novel Siloxane-Carbonate Soft Segments for Biomedical Applications, Journal of Polymer Science Part B-Polymer Physics 49(12) (2011) 865-872.

[2] O.C.M. Pereira-Junior, S.C. Rahal, P. Iamaguti, S.L. Felisbino, P.T. Pavan, L.C. Vulcano, Comparison between polyurethanes containing castor oil (soft segment) and cancellous bone autograft in the treatment of segmental bone defect induced in rabbits, Journal of Biomaterials Applications 21(3) (2007) 283-297.

[3] A.M. Diez-Pascual, A.L. Diez-Vicente, Wound Healing Bionanocomposites Based on Castor Oil Polymeric Films Reinforced with Chitosan-Modified ZnO Nanoparticles, Biomacromolecules 16(9) (2015) 2631-2644.

[4] O.C.M. Pereira, S.C. Rahal, J.F. Lima-Neto, F.D. Landim-Alvarenga, F.O.B. Monteiro, In vitro evaluation of three different biomaterials as scaffolds for canine mesenchymal stem cells, Acta Cirurgica Brasileira 28(5) (2013) 353-360.

[5] R. Gallego, J.F. Arteaga, C. Valencia, J.M. Franco, Isocyanate-Functionalized Chitin and Chitosan as Gelling Agents of Castor Oil, Molecules 18(6) (2013) 6532-6549.

[6] J.O. Kim, J.K. Park, J.H. Kim, S.G. Jin, C.S. Yong, D.X. Li, J.Y. Choi, J.S. Woo, B.K. Yoo, W.S. Lyoo, J.A. Kim, H.G. Choi, Development of polyvinyl alcohol-sodium alginate gel-matrix-based wound dressing system containing nitrofurazone, International Journal of Pharmaceutics 359(1-2) (2008) 79-86.

[7] L. Bao, W. Yang, X. Mao, S.S. Mou, S.Q. Tang, Agar/collagen membrane as skin dressing for wounds, Biomedical Materials 3(4) (2008) 1-7.

[8] S. Das, P. Pandey, S. Mohanty, S.K. Nayak, Insight on Castor Oil Based Polyurethane and Nanocomposites: Recent Trends and Development, Polymer-Plastics Technology and Engineering 56(14) (2017) 1556-1585.

[9] M. Desroches, M. Escouvois, R. Auvergne, S. Caillol, B. Boutevin, From Vegetable Oils to Polyurethanes: Synthetic Routes to Polyols and Main Industrial Products, Polymer Reviews 52(1) (2012) 38-79.

[10] L.Q. Zhang, M. Zhang, L.H. Hu, Y.H. Zhou, Synthesis of rigid polyurethane foams with castor oil-based flame retardant polyols, Industrial Crops and Products 52 (2014) 380-388.

[11] H. Mutlu, M.A.R. Meier, Castor oil as a renewable resource for the chemical industry, European Journal of Lipid Science and Technology 112(1) (2010) 10-30.

[12] M.M. Li, Y. Xiao, Y. Chen, H. Ni, J. Cai, X.M. Wang, P.R. Chang, D.P. Anderson, Soy proteinmodified waterborne polyurethane biocomposites with improved functionality, Rsc Advances 6(16) (2016) 12837-12849.

[13] P.K. Saxena, S.R. Srinivasan, J. Hrouz, M. Ilavsky, THE EFFECT OF CASTOR-OIL ON THE STRUCTURE AND PROPERTIES OF POLYURETHANE ELASTOMERS, Journal of Applied Polymer Science 44(8) (1992) 1343-1347.

[14] S. Allauddin, R. Narayan, K. Raju, Synthesis and Properties of Alkoxysilane Castor Oil and Their Polyurethane/Urea-Silica Hybrid Coating Films, Acs Sustainable Chemistry \& Engineering 1(8) (2013) 910-918.

[15] A. Mathew, S. Kurmvanshi, S. Mohanty, S.K. Nayak, Sustainable production of polyurethane from castor oil, functionalized with epoxy- and hydroxyl-terminated poly(dimethyl siloxane) for biomedical applications, Journal of Materials Science 53(5) (2018) 3119-3130.

[16] Y. Xia, R.C. Larock, Preparation and Properties of Aqueous Castor Oil-based PolyurethaneSilica Nanocomposite Dispersions through a Sol-Gel Process, Macromolecular Rapid Communications 32(17) (2011) 1331-1337.

[17] K.M.S. Meera, R.M. Sankar, S.N. Jaisankar, A.B. Mandal, Physicochemical Studies on Polyurethane/Siloxane Cross-Linked Films for Hydrophobic Surfaces by the Sol-Gel Process, Journal of Physical Chemistry B 117(9) (2013) 2682-2694. 
[18] D.M. Bechi, M.A. de Luca, M. Martinelli, S. Mitidieri, Organic-inorganic coatings based on epoxidized castor oil with APTES/TIP and TEOS/TIP, Progress in Organic Coatings 76(4) (2013) 736-742.

[19] L.C. Keong, A.S. Halim, In Vitro Models in Biocompatibility Assessment for Biomedical-Grade Chitosan Derivatives in Wound Management, Int. J. Mol. Sci. 10(3) (2009) 1300-1313.

[20] P. Roach, D. Farrar, C.C. Perry, Interpretation of protein adsorption: Surface-induced conformational changes, Journal of the American Chemical Society 127(22) (2005) 8168-8173. [21] K. Rechendorff, M.B. Hovgaard, M. Foss, V.P. Zhdanov, F. Besenbacher, Enhancement of protein adsorption induced by surface roughness, Langmuir 22(26) (2006) 10885-10888.

[22] P. Thevenot, W.J. Hu, L.P. Tang, Surface chemistry influences implant biocompatibility, Current Topics in Medicinal Chemistry 8(4) (2008) 270-280.

[23] G. Anand, S. Sharma, A.K. Dutta, S.K. Kumar, G. Belfort, Conformational Transitions of Adsorbed Proteins on Surfaces of Varying Polarity, Langmuir 26(13) (2010) 10803-10811.

[24] Z. Adamczyk, Modeling adsorption of colloids and proteins, Current Opinion in Colloid \& Interface Science 17(3) (2012) 173-186.

[25] J.L. Ortega-Vinuesa, P. Tengvall, I. Lundstrom, Molecular packing of HSA, IgG, and fibrinogen adsorbed on silicon by AFM imaging, Thin Solid Films 324(1-2) (1998) 257-273.

[26] C.E. Giacomelli, M.J. Esplandiu, P.I. Ortiz, M.J. Avena, C.P. De Pauli, Ellipsometric study of bovine serum albumin adsorbed onto $\mathrm{Ti} / \mathrm{TiO} 2$ electrodes, Journal of Colloid and Interface Science 218(2) (1999) 404-411.

[27] D. Johannsmann, Viscoelastic, mechanical, and dielectric measurements on complex samples with the quartz crystal microbalance, Physical Chemistry Chemical Physics 10(31) (2008) 4516-4534. [28] D. Johannsmann, I. Reviakine, E. Rojas, M. Gallego, Effect of Sample Heterogeneity on the Interpretation of QCM(-D) Data: Comparison of Combined Quartz Crystal Microbalance/Atomic Force Microscopy Measurements with Finite Element Method Modeling, Analytical Chemistry 80(23) (2008) 8891-8899.

[29] L. Perez-Fuentes, C. Drummond, J. Faraudo, D. Bastos-Gonzalez, Adsorption of Milk Proteins (beta Casein and beta-Lactoglobulin) and BSA onto Hydrophobic Surfaces, Materials 10(8) (2017).

[30] B. Jachimska, K. Tokarczyk, M. Lapczynska, A. Puciul-Malinowska, S. Zapotoczny, Structure of bovine serum albumin adsorbed on silica investigated by quartz crystal microbalance, Colloids and Surfaces a-Physicochemical and Engineering Aspects 489 (2016) 163-172.

[31] K.R. Xu, M.M. Ouberai, M.E. Welland, A comprehensive study of lysozyme adsorption using dual polarization interferometry and quartz crystal microbalance with dissipation, Biomaterials 34(5) (2013) 1461-1470.

[32] J.H. Teichroeb, J.A. Forrest, L.W. Jones, J. Chan, K. Dalton, Quartz crystal microbalance study of protein adsorption kinetics on poly(2-hydroxyethyl methacrylate), Journal of Colloid and Interface Science 325(1) (2008) 157-164.

[33] A. Theodoratou, L. Bonnet, P. Dieudonne, G. Massiera, P. Etienne, J.J. Robin, V. Lapinte, J. Chopineau, J. Oberdisse, A. Aubert-Pouessel, Vegetable oil hybrid films cross-linked at the air-water interface: formation kinetics and physical characterization, Soft Matter 13(26) (2017) 4569-4579.

[34] F. Chivrac, H. Angellier-Coussy, V. Guillard, E. Pollet, L. Averous, How does water diffuse in starch/montmorillonite nano-biocomposite materials?, Carbohydrate Polymers 82(1) (2010) 128-135.

[35] G. Sauerbrey, VERWENDUNG VON SCHWINGQUARZEN ZUR WAGUNG DUNNER SCHICHTEN UND ZUR MIKROWAGUNG, Zeitschrift Fur Physik 155(2) (1959) 206-222.

[36] F.S. Ruggeri, G. Longo, S. Faggiano, E. Lipiec, A. Pastore, G. Dietler, Infrared nanospectroscopy characterization of oligomeric and fibrillar aggregates during amyloid formation, Nature Communications 6 (2015) 9.

[37] D. Necas, P. Klapetek, Gwyddion: an open-source software for SPM data analysis, Central European Journal of Physics 10(1) (2012) 181-188.

[38] L. Costa, A. Andriatis, M. Brennich, J.M. Teulon, S.W.W. Chen, J.L. Pellequer, A. Round, Combined small angle X-ray solution scattering with atomic force microscopy for characterizing radiation damage on biological macromolecules, Bmc Structural Biology 16 (2016).

[39] Y. Mulazim, E. Cakmakci, M.V. Kahraman, Preparation of photo curable highly hydrophobic coatings using a modified castor oil derivative as a sol-gel component, Progress in Organic Coatings 72(3) (2011) 394-401. 
[40] Y. Mulazim, E. Cakmakci, M.V. Kahraman, Photo-curable highly water-repellent nanocomposite coatings, Journal of Vinyl \& Additive Technology 19(1) (2013) 31-38.

[41] P. Wu, A.C. Fisher, P.P. Foo, D. Queen, J.D.S. Gaylor, IN-VITRO ASSESSMENT OF WATERVAPOR TRANSMISSION OF SYNTHETIC WOUND DRESSINGS, Biomaterials 16(3) (1995) 171-175.

[42] C. Bourlieu, V. Guillard, H. Powell, B. Valles-Pamies, S. Guilbert, N. Gontard, Performance of lipid-based moisture barriers in food products with intermediate water activity, European Journal of Lipid Science and Technology 108(12) (2006) 1007-1020.

[43] D. Queen, J.D.S. Gaylor, J.H. Evans, J.M. Courtney, W.H. Reid, THE PRECLINICAL EVALUATION OF THE WATER-VAPOR TRANSMISSION RATE THROUGH BURN WOUND DRESSINGS, Biomaterials 8(5) (1987) 367-371.

[44] R. Xu, H.S. Xia, W.F. He, Z.C. Li, J. Zhao, B. Liu, Y.Z. Wang, Q. Lei, Y. Kong, Y. Bai, Z.H. Yao, R.S. Yan, H.S. Li, R.X. Zhan, S.S. Yang, G.X. Luo, J. Wu, Controlled water vapor transmission rate promotes wound-healing via wound re-epithelialization and contraction enhancement, Scientific Reports 6 (2016).

[45] M. Singh, H. Chand, K.C. Gupta, The studies of density, apparent molar volume, and viscosity of bovine serum albumin, egg albumin, and lysozyme in aqueous and RbI, CsI, and DTAB aqueous solutions at $303.15 \mathrm{~K}$, Chemistry \& Biodiversity 2(6) (2005) 809-824.

[46] R. Giordano, A. Salleo, S. Salleo, F. Wanderlingh, VISCOSITY AND DENSITY OF LYSOZYME IN WATER, Physics Letters A 70(1) (1979) 64-66.

[47] R. Das, S. Pradhan, S. Biswas, P. Sharma, A. Ghosh, R. Bandyopadhyay, P. Pramanik, Aliphatic amines vapours detection by quartz crystal microbalance sensor, Sensors and Actuators B-Chemical 198 (2014) 94-101.

[48] K.O. Evans, G. Biresaw, Quartz crystal microbalance investigation of the structure of adsorbed soybean oil and methyl oleate onto steel surface, Thin Solid Films 519(2) (2010) 900-905.

[49] T. Nezu, T. Masuyama, K. Sasaki, S. Saitoh, M. Taira, Y. Araki, Effect of pH and Addition of Salt on the Adsorption Behavior of Lysozyme on Gold, Silica, and Titania Surfaces Observed by Quartz Crystal Microbalance with Dissipation Monitoring, Dental Materials Journal 27(4) (2008) 573-580.

[50] C.C.F. Blake, D.F. Koenig, G.A. Mair, A.C.T. North, D.C. Phillips, V.R. Sarma, STRUCTURE OF HEN EGG-WHITE LYSOZYME - A 3-DIMENSIONAL FOURIER SYNTHESIS AT 2A RESOLUTION, Nature 206(4986) (1965) 757-761.

[51] T.J. Su, J.R. Lu, R.K. Thomas, Z.F. Cui, J. Penfold, The conformational structure of bovine serum albumin layers adsorbed at the silica-water interface, Journal of Physical Chemistry B 102(41) (1998) 8100-8108.

[52] T.J. Su, J.R. Lu, R.K. Thomas, Z.F. Cui, Effect of $\mathrm{pH}$ on the adsorption of bovine serum albumin at the silica water interface studied by neutron reflection, Journal of Physical Chemistry B 103(18) (1999) 3727-3736.

[53] C.D. Reyes, T.A. Petrie, A.J. Garcia, Mixed extracellular matrix ligands synergistically modulate integrin adhesion and signaling, Journal of Cellular Physiology 217(2) (2008) 450-458.

[54] M. Zelzer, D. Albutt, M.R. Alexander, N.A. Russell, The Role of Albumin and Fibronectin in the Adhesion of Fibroblasts to Plasma Polymer Surfaces, Plasma Processes and Polymers 9(2) (2012) 149-156.

[55] C.M. Elkins, Q.M. Qi, G.G. Fuller, Corneal Cell Adhesion to Contact Lens Hydrogel Materials Enhanced via Tear Film Protein Deposition, Plos One 9(8) (2014). 